\title{
CO2 Economic Cost Analysis in the Process of Economic Development in Indonesia
}

\section{Kasman Karimi, Evi Susanti Tasri, and Riza Sepriana}

Economic Development, Faculty of Economics, University of Bung Hatta

\section{Abstract}

Deteriorating environmental conditions can be an obstacle in creating a sustainable economic development that takes care of all parties. This study Aimed to assess the effects of Foreign Direct Investment (FDI), the Domestic Investment (DCl), the Gross Domestic Product (GDP), population, and Industrial Sector Contribution to Air Pollution. The Data used is secondary Data Obtained on the report of the Central Statistics Agency (BPS) of data in 1996 to 2011 in particular. Examined the data included the data of FDI, domestic investment, GDP, population, Contribution of Industrial Sector and Air Pollution. Data were Analyzed using the method of multiple regression test, Classical

Corresponding Author: Kasman Karimi

kasmankarimi@bunghatta.ac.id

Received: 18 January 2019 Accepted: 24 March 2019 Published: 31 March 2019

Publishing services provided by Knowledge E

(c) Kasman Karimi et al. This article is distributed under the terms of the Creative Commons Attribution License, which permits unrestricted use and redistribution provided that the original author and source are credited.

Selection and Peer-review under the responsibility of the First ELEHIC Conference Committee.

\section{G OPEN ACCESS}

Assumption Test. Obtained results show that together the Gross Domestic Product and Foreign Investment significant effect on Air Pollution. The research conclusion from this is that there are three independent variables have no significant against Air Pollution. Reviews These variables namely the Domestic Investment, Population, and Industry Sector Contribution.

Keywords: Air Pollution, FDI, domestic investment, GDP, population

\section{Introduction}

Worsening environmental conditions can be an obstacle in creating a sustainable economic development that takes care of all the parties. Development of the industrial sector is a top priority in the planning of the developing countries (NSB). This happens because the industrial sector is considered as the leading sector that could encourage the development of other sectors, such as services and agriculture sector [1]

Created pollution havens in countries with lower environmental standards, Pollution haven hypothesis refers to the possibility that trade liberalization led to the movement of industrial pollution of the countries to the level of high-income countries that have weaker environmental standards [2]. Pollution is closely linked to economic growth. Liberalization of trade and foreign direct investment (FDI) is an important engine for 
economic growth. Way trade between the countries can be affected by environmental regulations.

Pollution haven hypothesis argue that when countries have large industries trying to set up factories or offices abroad in the hope of easily get the resources and manpower by offering land and access material they need. Developing countries are easier to get resources and labor and environmental regulations are less stringent, and the opposite state of the strict environmental regulations become more expensive for the company. Thus, a company that invests physically abroad tend to find a country that has a low environmental regulations or tight.

Air pollution is one environmental damage, A decrease in air quality due to entry of harmful elements in the air or the earth's atmosphere. Dangerous elements that go into the atmosphere can be a carbon monoxide (CO), nitrogen dioxide (So2), chlorofluorocarbons (CFCs), sulfur dioxide (SO2), hydrocarbons ( $\mathrm{HC}$ ), Benda Particulates, Lead (Pb), and Carbon Diaoksida (CO2). These elements can be referred to as pollutants or types of air pollutants.

States that the economic approach is one approach that can be used to overcome the problem of scarcity of natural resources and environmental damage.[3] The relationship between economic growth and environmental pollution, implicit in hunungan pattern that became known as the Environmental Kuznezts Curve (EKC). Kuznets curve concept to explain the pattern of the relationship between the measurement of environmental quality with per capita income.[4]

Seeing the magnitude of the phenomenon of damage from the environment due to these development activities, the researchers were interested in conducting research on "Cost Analysis of Economic Co2 in the Economic Development Process in Indonesia".

Based on the background of the above problems, the formulation of the problem in this research are:

1. How does it effect the Gross Domestic Product, Foreign Investment, Domestic Investment, Population, and Industry Sector Contribution to Air Pollution.

2. Whether there is evidence of Pollution Haven Hypothesis $(\mathrm{PHH})$ in Indonesia.

Based on the formulation of the above problems, the hypothesis in this study are as follows:

1. Suspected variable Gross Domestic Product, Foreign Investment, Domestic Investment, Population, and Industry Sector Contribution to Air Pollution.

2. Whether there is evidence of Pollution Haven Hypothesis $(\mathrm{PHH})$ in Indonesia. 


\section{Theoretical Background and Literatute Review}

\subsection{Air pollution}

At its core is the entry understanding of air pollution, or the mixing of hazardous elements into the atmosphere that could cause environmental damage, disturbances in human health as well as generally degrade air quality in the neighborhood. Air pollution might occur inside and outside the room (indoor and outdoor). Sources of air pollution can come from natural and volcanic activity, forest fires, dust storms and radiation from natural radioactive substances such as radon. Source of pollutants originating from human activity are from motor vehicles, the burning of fossil fuels in stationary place (instationary fuel combustion sources), disposal of solid waste, industrial processes and others. Some are derived from human activities from within the room, such as smoking, use of stove, machine paper multiplier,

\subsection{Gross domestic product}

Gross Domestic Product or GDP (Gross Domestic Product) is the economic statistics the most attention because it is considered as the best single measure of the welfare of the community. The underlying case for GDP measures two things at once: the total income of everyone in the economy and total state spending for purchase of goods and services results from the economy. Reason GDP can perform measurement of total income and expenses due to the economy as a whole, income must equal expenditure.

To get a measure of the amount of production that is not affected by changes in prices, we use real GDP (real GDP) which assesses the production of goods and services at a fixed price. Real GDP using the principal fixed price to determine the value of goods and services produced in the economy. Because real GDP is not influenced price changes, changes in real GDP reflects only the changes in the amount of goods and services produced. Thus, real GDP is a measure of goods and services produced in the economy.[5]

\subsection{Foreign investment}

Direct investment or also called foreign investment (PMA) is a form of investment by building, buying or acquiring a company. Foreign investment (FDI) has positive externalities such as the entry of stable inflows of foreign capital, increased employment 
opportunities, increased national income, improved balance of payments, and transfer of technology and managerial skills from multinational companies. This positive externality is the main goal of government policy in attracting FDI. Each country applies various tools to achieve policy objectives regarding FDI. The investment incentive system is a system that is often used lately as a typical tool to attract FDI. For this reason, the right set of policies must be chosen to maximize the positive influence of FDI on the country's economy. If a mismatch occurs between the purpose and the device, not only does the policy become inefficient, but there may be a negative effect on the structure of the larger economy. The study conducted empirically tests the economic effects and types of investment incentives, and looks at the correlation between FDI policy objectives and various tools in 4 countries as a case study. This study yields the understanding that there must be a clear correlation between the objectives of FDI policy and investment incentives, and a country must consider this when implementing policies to attract FDI.[6] Foreign direct investment (FDI) or foreign direct investment (FDI) has more advantages. In addition to its permanent or long-term nature, foreign investment contributes to technology transfer, transferring management skills and opening new jobs. This employment is important to note, given that the problem of providing employment is a problem that is quite dizzying for the government. Foreign investment is a form of economic openness other than international trade.[7] Kappel states that the concept of openness benefits the economy through international trade, international capital transactions and the exchange of international knowledge and information. Openness in terms of foreign capital can accelerate economic growth because with foreign investment coming in, it can add factors to domestic production both in terms of quantity and quality which then drives economic growth.

In an open economy, the world financial market is another source of domestic investment and a source of outflows for domestic savings. In this connection, foreign direct investment plays an important role in pushing the rate of economic growth for several reasons [8]: (1) countries can access technology from more developed countries and therefore hold a leading role in technological improvements for recipient countries (2) direct foreign investment can promote growth through the creation of spillover effects. (3) foreign companies tend to be more productive than local companies, and (4) if there is a complementary relationship between foreign direct investment and trade, PMA can increase the volume of international trade.

The growth of foreign direct investment made by the private sector, namely, the investment funds are directly used to carry out business activities or to hold equipment or production facilities such as buying land, opening factories, bringing in machinery, 
buying raw materials, etc. in third world countries has been going very fast in the last few decades. But unfortunately the attention of investors is only focused on maximizing profits or the level of yield for every penny of capital they invest. That is why more than 90 percent of private foreign investment funds have flowed to advanced industrial countries and some developing countries whose economies are the most dynamic and have relatively rapid growth.[9]Foreign investment (PMA) As one type of investment has a very large role in development. Foreign capital can enter a country in the form of private capital and / or state capital. Private foreign capital can take direct investment and indirect investment.[10]There are 4 things that constitute a positive contribution of foreign private investment to national development in the recipient country (GDP growth), namely:

1. Its role in filling in the gap or resource gap between the level of investment targeted (desired) and the actual number of domestic savings that can be mobilized.

2. Its role fills the gap in the target amount of foreign exchange needed and the actual amount of foreign exchange from export income plus net foreign assistance (trade gap).

3. Its role fills the gap in the target of government tax revenues and the amount of actual tax that can be collected.

4. Its role fills the gap in the fields of management, entrepreneurial spirit, production technology, and work skills that are expected to operate in the developing countries concerned [9]

\subsection{Domestic investment}

Domestic Investment ( $\mathrm{DCl}$ ) as the domestic resources is the key to national economic growth. On one hand, it reflects the effective demand, on the other hand it creates productive efficiency for production in the future. The process of this investment resulted in national output in a variety of ways. Investment in capital goods not only increase production but also increase the manpower. Formation or capital investment this will bring moving towards technological advancement. Advances in technology in turn bring savings towards specialization and large-scale production. Thus, domestic menghasilakn magnitude increase in national output, income and employment, there by solving the problem of inflation and balance of payments. As well as making the economy free from the burden of foreign debt. Sources that can be directed to capital formation was the increase in national income, consumption reduction, promotion of savings, the 
establishment of financial institutions, mobilizing gold deposits, increase profits, fiscal measures and monetary and forth. The most effective domestic sources, namely savings. Government savings and masyaarakat very important in the formation of capital.

\subsection{Population}

Population is an important element in economic activities as well as efforts to build an economy for the population supply of labor, skilled labor, power company leader entrepreneurs in creating economic activity [11].

In theory resident, Thomas Robert Malthus stated that population will exceed the amount of the food supply is needed. Furthermore, Malthus was very concerned that the time period required by the population to multiply two numbers are very short, he described that if no restrictions, the population tends to grow exponentially. So that there is an imbalance between the number of people and inventory foodstuffs. Within 200 years, the comparisons will be 256: 9 .

\subsection{Industrial sector contribution (KSI)}

Industry is livelihoods that uses skill and diligence work and the use of tools in the processing of agricultural products and their distribution as a baseline. While the industry is the order and all activities related to industrial activities. Enterprises assembly or assembling and repair are part of the industry. The results of the industry not only in the form of goods, but also in the form of services. Moreover, the notion of industries according to the law on the industry is the economic activity that processes raw materials, raw materials, semi-finished and / or finished goods into goods of higher value to the user, including design and engineering activities of the industry. Industry generally known as the chain of efforts to further meet the needs of (economic) associated with the earth, that is, after agriculture, plantation and mining are closely linked to the land. The position of the industry further away from land, which is the base of economy, culture and politics.

\section{Research Methodology}




\subsection{Types and sources of data}

The data used as the analysis of secondary data that is collected from various agencies such as the Central Statistics Agency (BPS), the data of the Environment of the Regional Environmental Agency and other related agencies. In addition secondary data obtained also from many previous studies that have relevance to the study conducted.

\subsection{Method of collecting data}

To complete virgin and references required in the preparation of this paper is to library research and field research.

\subsubsection{Data analysis method}

In this research using quantitative research methods using time series data. This analysis uses the least squares regression method or OLS (Ordinary Least Sqare) with adopt kirkulaks models [13]. The model used in this study are:

$\log (C O 2)=\beta 0++\log (\mathrm{GDP})+\log (\mathrm{PMA})+\log ($ Domestic $)+\log ($ Population$)+\log (\mathrm{KSI})$

Where:

$$
\begin{aligned}
& \mathrm{Y}=\mathrm{CO}_{2} \text { (air pollution) } \\
& \mathrm{X} 1=\text { Gross Domestic Product (GDP) } \\
& \mathrm{X}_{2}=\text { Foreign Direct Investment (FDI) } \\
& \mathrm{X}_{3}=\text { Domestic Investment (DCI) } \\
& \mathrm{X} 4=\text { Population } \\
& X 5=\text { Contributions Sector Industry }
\end{aligned}
$$

\section{Results and Discussion}

Based on the results of the regression equation the results are as follows:

$$
\begin{aligned}
& \text { Lpolusi }=-6.552779+1.162863 \text { LPDB-0.086347LPMA-0.086347LPMDN+0.574873LPDDK+0.001029KSI + } \\
& \begin{array}{llllll}
\text { T-test } & (4.719961) & (-2.517976) & (-1.704195) & (0.932798) & (0.310419)
\end{array} \\
& \text { F-test }=61.77391 \\
& R 2=0.952959 \\
& \alpha=5 \%
\end{aligned}
$$




\section{Classic Assumption Test}

\subsection{Normality test}

TABLE 1: Normality Test Results.

\begin{tabular}{l|c|}
\hline Jarque-Bera & 1.165487 \\
\hline Probability & 0.558364 \\
\hline Source: Estimation Results & \\
\hline
\end{tabular}

From the above results it can be seen that the probability of 0.558364 and will be compared with $5 \%$ alpha. Thus, $0.56>0.05$ then $\mathrm{HO}$ is accepted and Ha rejected. Thus, it can be concluded that the data used in this study normal distribution.

\subsection{Test multicollinearity}

Multikolinieritas test results can be seen that the correlation coefficient $(r)$ is smaller than 0.85 (correlation coefficient $<0.85$ ). So with this we can conclude that all independent variables used in this study has been free from the problem of colinearity.

\subsection{Test Heteroskidastity}

Based on the test results heteroskedastisitas with white test above, we can see that the probability Obs * R-squared is equal to 0.1800 and the value will be compared with $5 \%$ alpha. So,0.1800>0.05. It can be concluded that in this study has been free from the problem of heteroscedasticity.

\subsection{Test Autokolerasi}

To find out if this is the case study autocorrelation problem or not, then the autocorrelation test will be done by looking at the value of the Durbin-Watson statistic. In this study, the amount of data used as many as 16 years $(n=16)$ and the number of independent variables used is five $(\mathrm{k}=5)$. Based on the Durbin Watson table $\mathrm{dL}$ value $0615=$ and value $\mathrm{dU}=2,157$, while the value of Durbin Watson from the results table Recourse is equal to 2.394289it can be concluded that the data are in quadrant $\leq \mathrm{DW} d \mathrm{dU} d \mathrm{~L} \leq 4-$ ie $\leq$ 2:39 2:16 $\leq 3.38$ meaning that data is no autocorrelation among the independent variables. 


\section{Testing Statistics}

\subsection{Test the coefficient of determination (R2)}

Based on estimates, it can be seen that the coefficient of determination obtained at 0.952959. means that the variance of the rise and fall of Air Pollution clarified by the variable Gross Domestic Product (X1), Foreign Direct Investment (X2), Domestic Investment (X3), Population (X4) and Contribution of Industrial Sector (X5) of 95.30\% and $4.70 \%$ is explained by other variables outside the model.

\subsection{T-test}

- Based on the results of the above regression, regression results in the table shows that the Gross Domestic Product probalita 0.0008.ini means prob <alpha (0.05) which means that $\mathrm{HO}$ is rejected and $\mathrm{Ha}$ accepted.

So Domestic Product Gross significant effect on Air Pollution with a confidence level of $95 \%$.

- The value of the variable probability of Foreign Investment in the results table regression of 0.0305 , this means that 0.0305 <alpha $(0.05)$ which means that $\mathrm{HO}$ is rejected and $\mathrm{Ha}$ accepted.

So the Foreign Investment significant effect on Air Pollution with a confidence level of $95 \%$.

- The value of the variable probability domestic investment in the regression results table for 0.1192, this means that $0.1192>$ alpha (0.05) which means that $\mathrm{HO}$ is accepted and Ha rejected.

So domestic investment no significant impact on Air Pollution with a confidence level of $95 \%$.

- Residents variable probability value in the results table for regression 0.3729 , this means that $0.3729>$ alpha (0.05) which means that $\mathrm{HO}$ is accepted and $\mathrm{Ha}$ rejected.

So residents no significant effect on the Air Pollution confidence level of $95 \%$.

- Value Industry Sector Contribution probability variables in the results table for regression 0.7626 , this means that $0.7626>$ alpha $(0.05)$ which means that $\mathrm{HO}$ is accepted and Ha rejected. 
So the Industrial Sector Contribution no significant effect on Air Pollution with a confidence level of $95 \%$.

\subsection{F-test}

Based on the results of the regression equation can be seen the probability value of value of 0.000000 than the value of alpha $5 \%$. It means that decisions can be taken is $\mathrm{HO}$ rejected and $\mathrm{Ha}$ accepted so it can be inferred that the entire free variable Gross Domestic Product (X1), Foreign Direct Investment (X2), Domestic Investment (X3), PopuIation (X4), and Contribution of Industrial Sector (X5) is able to influence the dependent variable Pollution $(Y)$.

\subsection{Pollution haven hypothesis testing}

Based on the results of multiple linear regression it can be seen the coefficient of Foreign Investment amounting to -2.517679 , from these results it can be stated that the pollution haven hypothesis does not occur in Indonesia.

\section{Conclusion}

Based on the results of multiple linear regression equation with the discussion of the results of some tests in this study can be summarized as follows:

1. The results of this study indicate that Gross Domestic Product and Foreign Investment have a significant effect on Air Pollution, while Domestic Investment, Population and Industrial Sector Contributions have no significant effect on Air Pollution.

Based on the overall test shows that there is a significant relationship between the independent variables (GDP, PMA, PMDN, Population, Industrial Sector Contributions) to the dependent variable (Air Pollution).

2. Based on the results of multiple linear regression it can be seen the coefficient value of Foreign Investment is -0.082623 . From these results it can be stated that the pollution haven hypothesis did not occur in Indonesia. 


\section{References}

[1] Arsyad, Lincolin. (2010). Ekonomi Pembangunan Edisi Ke-5. Upp Stim Ykpn. Yogyakarta.

[2] Copeland, BRA Taylor, MS (2004). "Trade, Growth And The Environment." Journal of Economic Literature $\mathbf{4 2}$ 1, P.771

[3] Rukmana, Didi. (2012). Economic Environment And Human Resources, Timur.Makassar flow.

[4] Gene M. Grossman and Alan B. Krueger, The Quarterly Journal of Economics, Vol. 110, No. 2, (May, 1995), pp. 353-377 Published by: The MIT Press

[5] Mankiw, N. Gregory, et al. (2006). Principles Of Macroeconomics 3rd Ed Canadian Toronto: Thomson Nelson.

[6] Lim, Sung-Hoon. (2000). "Foreign Direct Investment Policy And Incentive OECD." Foreign Direct Investment Conference In South East Square: Implementing Best Practice Policy 8 to 9 November. Vienna.

[7] Kappel, Rolf. (2003). "Opennes, Institutions And Policies: Determinants Of GloblitationAnd Economic Growth In Developing Countries. The Pakistan Development Review, 42: 4 Part I (Winter 2003) pp. 395-416."

[8] Alguacil, Ma Taresa \& Coadros, Ana \& Orts., Vicente (2002). "Foreign Directlnvesment, Domestic Exports And Performance In Mexico: A Causality Analysis." Economic Letters, Elsevier Vol. 77 (3), Pages 371-376, November.

[9] Todaro, Michael. P. (2004). Economic Development In the Third World, Volume 1 (Edisi8).Jakarta: Erland.

[10] Jhingan, ML (2002). Economic Development and Planning. Pt King Grafindo Persada: Jakarta.

[11] Sukirno, Sadono. (2005). Micro Economic Theory Introduction Third Edition. PT.Rajagrafindo Persada: Jakarta.

[12] Kirkulak, Berna, Bin Qiu and Wei Yin. (2011). The Impact of FDI on water quality: evidence from China. Journal of Chinese foreign economic and trade studies. Vol. 4 2 